\title{
ADVOKASI TERHADAP PELACURAN ANAK DI LOKALISASI DOLLY SURABAYA
}

\author{
Hartono \\ Institut Agama Islam Negeri Sunan Ampel Surabaya | judulsj@gmail.com
}

\begin{abstract}
This article discusses about advocacy against child prostitution in Dolly-Surabaya. Child prostitution is an act that violates the fundamental rights of the children from any kind of exploitation activities. The people who cause prostitution are to be punished in accordance with the applied regulations. Advocacy on child prostitution in Dolly is where the act of prostitution is not getting any penalties or sanctions because the child only has an obligatory capability and not an act capability. The parties that led to the child victims of prostitution should be punished by the assumption that they have done fraud and coercion. Moreover, child prostitution is a form of human trafficking. The advocacy dedicated to child as the victim of prostitution is: first, litigation advocacy with the target of those children's fundamental rights which have been violated by others can be restored; second, budgetary advocacy with the goal of keeping the budget managed by the government can be allocated appropriately to children who become the victim of prostitution; and third, policy advocacy with the aim of protecting the fundamental rights and improving the welfare of the children who become the victim of prostitution, both of morally and materially.
\end{abstract}

Keywords: Advocacy, child prostitution, Dolly localization.

Abstrak: Artikel ini membahas tentang advokasi terhadap pelacuran anak di lokalisasi Dolly Surabaya. Pelacuran anak merupakan tindakan yang melanggar hak-hak dasar anak atas perlindungan dari segala jenis kegiatan eksploitatif yang mengharuskan orang yang menyebabkan terjadinya pelacuran mendapatkan hukuman sesuai dengan peraturan yang berlaku. Advokasi pelacuran anak di lokalisasi Dolly, adalah perbuatan pelacuran tersebut tidak mendapatkan hukuman atau sanksi dikarenakan anak hanya punya kapabilitas dalam kewajiban bukan kapabilitas perbuatan. Adapun pihak-pihak yang menyebabkan anak menjadi korban pelacuran harus mendapat hukuman dengan asumsi 
telah melakukan penipuan serta pemaksaan. Lebih dari itu, pelacuran anak merupakan bentuk dari perdagangan manusia atau trafficking. Adapun advokasi yang didedikasikan terhadap anak yang menjadi korban pelacuran adalah pertama, advokasi litigasi dengan target anak yang hak-hak dasarnya dilanggar oleh orang lain dapat dipulihkan kembali. Kedua, advokasi anggaran dengan tujuan agar anggaran yang dikelolah oleh pemerintah dapat dialokasikan tepat kepada anak yang menjadi korban pelacuran. Ketiga, advokasi kebijakan dengan tujuan melindungi hak-hak dasar dan meningkatkan kesejahteraan anak yang menjadi korban pelacuran, baik secara moril maupun materiil.

Kata Kunci: Advokasi, pelacuran anak, lokalisasi Dolly.

\section{Pendahuluan}

Perempuan dan anak adalah ciptaan tuhan yang maha kuasa yang perlu dilindungi harga diri dan martabatnya serta dijamin hak hidupnya untuk tumbuh dan berkembang sesuai dengan fitrah dan kodratnya, karena itu segala bentuk perlakuan yang mengganggu dan merusak hak-hak dasarnya dalam berbagai bentuk pemanfaatan yang tidak berperikemanusiaan harus dihentikan tanpa terkecuali.

Munculnya pelacuran atau prostitusi merupakan suatu bentuk penyakit sosial masyarakat yang harus dihentikan penyebarannya, karena merupakan suatu bentuk perbuatan yang terkutuk dan bertentangan dengan kepribadian bangsa Indonesia yang berfalsafah Pancasila. Apabila peraturan sudah menyeret anak gadis atau remaja yang merupakan tendensi adanya krisis moral harus segera diatasi, karena mereka merupakan generasi penerus pejuang bangsa Indonesia.

Keberadaan pelacuran sebagai suatu profesi sampai dengan hari ini terus menggerogoti di dalam kehidupan sosial masyarakat. Pelacuran sudah anggap sebagai penyebab menjalarnya penyakit kelamin, bahkan penyakit yang sampai hari ini belum dapat ditemukan obat dan penangkalnya, yakni AIDS. Pelacuran meskipun dianggap sebagai perusak rumah tangga ternyata ia 
tetap tegar, bahkan tingkat perkembangannya melebihi pertumbuhan dan perkembangan ekonominya.

Timbulnya gejala pelacuran di dalam masyarakat, khususnya dilakukan oleh anak usia di bawah umur atau anak baru gede (ABG), adalah kebanyakan faktor ekonomi dalam keluarganya, apalagi dalam krisis ekonomi, yang melanda seluruh masyarakat Indonesia pada saat ini. Bertolak dari pengakuan polos anak-anak yang menjadi korban, kita tentunya perihatin, terlebih karena sebagian di antara mereka ternyata dikorbankan, "dijual" dari daerah asalnya dan selalu diawasi untuk membayar hutang yang dibebankan kepadanya. ${ }^{1}$ Mula-mula dijebak secara licik atau dirayu dengan janji-janji dan bujukan manis para calo untuk dicarikan pekerjaan dengan gaji yang besar. Namun dalam kenyataan gadis-gadis itu dijadikan korban para calo dan orang mencari keuntungannya saja, dan secara tidak sadar mereka dijerumuskan ke dalam dunia pelacuran.

Pelacuran itu selalu ada pada semua negara, sejak zaman jahiliyah sampai zaman sekarang. Pelacuran senantiasa menjadi masalah sosial atau menjadi obyek urusan hukum, yang seiring dengan perkembangan teknologi, industri dan kebudayaan manusia, juga turut berkembang pula pelacuran dalam berbagai bentuk dan tingkatannya.

Setelah mengetahui faktor penyebab di atas, yang menjadi perhatian selanjutnya adalah penanggulangannya. Anak korban pelacuran dari tahun ke tahun sangat meningkat walaupun sudah ada penanggulangan dari pemerintah dan penanganan dari institusi atau lembaga pendukung seperti LSM yang menangani masalah tersebut.

Persoalannya adalah bahwa prostitusi itu bukanlah sifat bawaan atau bakat, melainkan dari hasil interaksi sosial, walaupun sudah diketahui sebab musababnya prostitusi itu sendiri, namun hingga sekarang langkah-langkah untuk memecahkan masalah ini 
belumlah ditemukan cara yang tepat, karena pemecahan masalah, malah akan menimbulkan suatu permasalahan baru.

"Di antara langkah yang telah dilakukan di berbagai negara, dalam usaha mengatasi masalah prostitusi ini antara lain ada yang berusaha melokalisir prostitusi dan ada pula yang membiarkan saja tanpa mengambil usaha melokalisasikan pelacur, kesemuanya itu bukanlah jaminan pemecahan masalah". ${ }^{2}$

Dalam menghadapi suatu profesi (pelacuran) yang dilakukan oleh para remaja sering kali suatu pesimis selalu timbul ke depan dengan menyatakan bahwa pelacuran tidak mungkin dapat dihapuskan. Walaupun pelacuran tidak dapat dihapuskan bukanlah berarti manusia tidak harus berupaya untuk mencegahnya atau sedapat mungkin menggulanginya serta pananganannya apabila gejala tersebut sudah terjadi. Hukum sebagai sarana pengendali sosial dalam menghadapi masalah pelacuran ini ternyata belum menunjukkan peranannya. Hal ini dapat disadari mengingat bahwa KUHP, undang-undang yang berlaku memang tidak mencantumkan pelacuran sebagai kejahatan yang tidak di pidana. Perbuatan yang dianggap sebagai perbuatan pidana adalah perbuatan mereka yang menyediakan tempat untuk terjadinya pelacuran, ${ }^{3}$ tetapi kenyataan yang terjadi justru adanya lokalisasi pelacuran dengan dalih pembinaan.

Berdasarkan uraian di atas, maka penulis tertarik ingin mengadakan penelitian atas advokasi terhadap anak korban pelacuran di lokalisasi Dolly serta pelaksanaan pengaturan hukumnya, baik menurut hukum pidana maupun hukum Islam.

\section{Letak Geografis Komplek Lokalisasi Dolly}

Kompleks pelacuran Dolly berada di kawasan Putat Jaya, Kecamatan Sawahan, Kotamadya Surabaya. Hanya sebuah jalan sepanjang kurang lebih 150 Meter dengan lebar sekitar 5 meter

\footnotetext{
${ }^{2}$ S. Imam Asyari, Patologi Sosial, (Surabaya: Usaha Nasional, 1983),74.

${ }^{3}$ R. Susilo, Kitab Undang-Undang Hukum Pidana (KUHP) Serta Komentar-Komentarnya, (Bogor: Politeia, 1995), 217.
} 
beraspal cukup halus, hasil proyek perbaikan kampung (kampung improvement project) tahun 1977. Tepatnya, kompleks pelacuran ini berlokasi di jalan Kupang Gunung Timur I. di sebelah selatannya berbatasan dengan jalan Kupang Gunung Timur V Raya. Kalau jalan Tunjungan dianggap sebagai pusat atau jantung kota Surabaya, kompleks pelacuran ini hanya bisa dicapai dalam waktu kurang lebih 10 menit dengan kendaraan bermotor. Rentangan antara pusat kota dengan kompleks pelacuran Dolly, ini kurang lebih 1,5 KM.

Seperti yang dikatakan pepatah lama, banyak jalan menuju Roma. Kompleks pelacuran Dolly inipun bisa dicapai dari berbagai arah. Dari sebelah timur lewat jalan Ronggo Warsito, atau bisa juga melalui jalan Girilaya. Sementara itu dari arah barat bisa dicapai melalui jalan raya Dukuh Kupang. Sementara itu jalan Jarak merupakan batas sebelah utara kompleks pelacuran ini (Dolly), dilalui juga oleh kendaraan umum (Bemo). Kendaraan umum ini juga menunjang mobilitas para pelacur penghuni kompleks pelacuran Dolly, tetapi becak-becak yang banyak mangkal di dalam kompleks tersebut lebih sering digunakan sebagai sarana bepergian mereka.

Kelurahan Putat Jaya ini seluas 136 hektar dan dari sekian banyak rukun warga (RW) yang di dalamnya, 7 rukun warga di antaranya berada dalam kompleks pelacuran. Kompleks pelacuran Dolly sendiri meliputi 3 rukun warga atau RW. Untuk nomor rumah atau wisma genap dihimpun sebagai RW 12 Putat Jaya C Timur, sedang yang bernomor ganjil dimasukkan dalam RW 6 Kupang Gunung Timur, dan sisanya sebagai RW 10 Putat Jaya Timur. 4 RW lainnya berada di lokasi pelacuran Jarak. Demikianlah 7 RW ini bagaikan pulau yang dikelilingi permukiman penduduk biasa.

Dahulu, daerah Putat Jaya termasuk kompleks pelacuran Dolly yang merupakan makam China. Baru sekitar tahun 1966 daerah ini "diserbu" para pendatang dengan menghancurkan bangunan-bangunan makam. Menurut informasi yang peroleh 
dari salah seorang penduduk yang saat itu turut kegiatan bongkarmembongkar, makam dibongkar karena dinyatakan oleh pemerintah daerah, makam China itu tertutup bagi jenazah baru, dan kerangka lama harus dipindahkan oleh para ahli warisnya.

Pada tahun itu, berdatangan orang-orang yang ingin mendapatkan tanah bekas makam. Cukup dengan cara membongkar bangunan makam, menggali kerangka yang ada, atau hanya meratakan gundukan makam tanpa menggali kerangka yang ada di dalamnya, kemudian menyatakan diri sebagai pemilik tanah tersebut.

Kompleks makam China tadinya meliputi daerah Girilaya, sekarang hingga batas makam Islam di daerah Putat Gede. Setahun setelah kompleks makam China itu dihuni oleh manusia hidup, pada tahun 1967 muncul seorang yang bernama Dolly Khavit seorang wanita yang konon dulunya juga pelacur, yang kemudian menikah dengan seorang pelaut Belanda. Dolly khavit inilah orang pertama kali yang mendirikan bordil di Kupang Gunung Timur I. Dolly Khavit ini dianggap sebagai "cikal bakal" kompleks pelacuran di Kupang Gunung Timur I, namanya diabadikan untuk kompleks pelacuran itu.

Munculnya wisma-wisma di kompleks pelacuran Dolly mulai pada sisi jalan sebelah barat, yang kemudian meluas ke sisi timur, bahkan sampai ke sebagian jalan jarak juga. Kehadiran wismawisma ini pada puncaknya pada tahun 1968/1969, dan daerah itu telah dipadati wisma-wisma dengan dekorasi interior yang mewah. ${ }^{4}$

Kompleks pelacuran ini sesungguhnya tidak resmi, dalam arti izin penggunaan bangunannya bukan sebagai bordil atau tempat pelacuran. "dulunya izin mendirikan bordil atau wisma ini hanya diperoleh dari kepolisian dengan menyebutkan izin untuk warung kopi yang dilayani perempuan-perempuan, "tutur Ketua RW 6 Kupang Gunung Timur, oleh sebab itu, tak mengherankan Kalau 
Lurah Putat Jaya menolak sebutan "lokalisasi pelacuran". "cukup sebut kompleks pelacuran, sebab surat keputusan wali kota madiyah daerah itu sebagai lokalisasi pelacuran hingga kini belum ada," kata Lurah Putat Jaya, bekas marinir itu. Bordil-bordil tersebut diketahui kehadirannya dan kemudian ditertibkan pemerintah daerah bekerja sama dengan kepolisian. ${ }^{5}$

Tidak semua tanah di sepanjang jalan Kupang Gunung Timur I yang menjadi ajang pelacuran dimanfaatkan sebagai wisma. Ada yang dijadikan rumah makan, toko, tempat parkir, penjahit, servis radio, serta gudang minuman.

Untuk lahan parkir tidak digunakan karcis resmi yang berasal dari Kotamadya. Mereka membuat sendiri dari kertas karton manila. Untuk sepeda motor dipungut biaya sebesar Rp. 1000.00 dan mobil Rp. 2000.00. lewat dari pukul 24.00 WIB untuk mobil dikenakan RP. 5000.00 dan sepeda motor Rp. 2500.00, kalau sampai "bermalam" hingga keesokan harinya dikenakan tarif Rp. 1.0000,00 untuk mobil dan Rp. 5000,00 untuk sepeda motor.

Kalau lagi ramai, terutama malam minggu atau tanggal muda, kurang lebih Rp. 70,000,00. sementara itu, kebanyakan bangunan makan yang berada di kompleks ini menempel pada wisma-wisma yang ada. Rumah makan ini berupa ruangan seluas kurang lebih 3 x 3 meter. Hal ini bisa dimengerti karena jarang orang datang makan di tempat tersebut. bisanya makanan dipesan dan dimakan orang-orang di wisma yang dikunjunginya. Tinggal menyuruh pelayan wisma memesankan makanan, dalam waktu singkat makanan sudah dikirim dan tersaji di hadapan sang pemesan.

Rumah tangga di daerah kompleks pelacuran ini hanya tersebar dibagian selatan jalan. Kecuali 5 rumah, 3 yang lainnya adalah rumah-rumah petak yang luasnya tak lebih dari 2 × 3 meter dengan kondisi yang tidak terlalu baik, dindingnya terbuat dari gedek bambu yang sudah rapuh dan berlubang disana-sini. ${ }^{6}$

${ }^{5}$ Hans Lumintang, Departemen Litbang Abdi Asih, Wawancara, Surabaya, 29 Maret 2007.

${ }^{6}$ Ibid. 
Demikianlah pola pemanfaatan tanah di kompleks pelacuran "Dolly". Nampak tidak hanya wisma-wisma bordil saja, melainkan berbagai macam kegiatan lain turut mengisi kawasan tersebut.

\section{Sistem Pelacuran di Kompleks Lokalisasi Dolly}

Mendengar ucapan "kompleks pelacuran", langsung pikiran orang akan melayang pada daerah dengan rumah yang berderetderet menyimpan beragam wanita. Mulai dari yang berwajah selangit dengan bentuk tubuh yang aduhai, hingga wajah-wajah kuyu dengan bentuk tubuh yang tak mampu menolong orang untuk bisa berimajinasi. Kehangatan tubuh-tubuh wanita ini bisa dinikmati siapa saja dengan imbalan uang yang relatif murah dibandingkan dengan kehormatan diri yang dijajakan mereka. "surga dunia", kata orang, agaknya membawa orang akan gambaran yang semarak sifatnya dengan sejuta impian. Di tempat yang namanya kompleks pelacuran ini orang bisa menemukan pengalaman-pengalaman seksual baru yang membebaskan orang agar bernafas lepas dari kepentingan norma-norma kesusilaan. Disini orang dapat mengumbar naluri primitifnya, menyalurkan nafsu seksualnya dengan sepuas-puasnya. Namun, sementara itu, bukan hanya gemerlap dan kesemarakan saja yang mewarnai kehidupan kompleks pelacuran. Di tempat ini pula bisa kita temukan ironi kehidupan yang menampilkan suasana yang temaram. ${ }^{7}$

Dari sisi yang lain, bisa kita temukan keremang-remangan, terutama dikalangan para penghuninya yang menekuni profesi sebagai pelacur, profesi yang bermodal dagingnya sendiri. Hidup bagaikan sebatang tebu, habis manis sepah dibuang. Selama masih menghasilkan uang bagi sang germo, selama itu pula mereka diperbolehkan tetap tinggal di bordilnya. Tetapi, begitu ia 
diserang sakit yang berkepanjangan dan tidak lagi memberikan hasil bagi sang germo, berlahirlah perjuangannya.

Gambaran sedemikian itu, juga melingkupi kehidupan di kompleks pelacuran di Dolly. Dibalik gemerlapnya lampu-lampu dan kemewahan interior yang menghiasi dan mewarnai wismawisma di sana, menyelinap pula suatu ketemaraman yang menggigit rasa kemanusiaan. Sandiwara-sandiwara kehidupan dipentaskan para wanita yang memilih pelacuran sebagai suatu profesi.

Tidak semua germo di kompleks pelacuran Dolly ini memiliki wisma yang diusahakannya. Mereka menyewa dari pemilik wisma yang dulunya mendapatkan tanah hanya dengan cara mematoki dan membongkar bangunan makam, kemudian membangun rumah-rumah untuk dipakai sebagai tempat usaha bordil. Dan ada juga wisma yang sudah berpindah tangan ke orang kedua, dibeli oleh germo penyewanya atau berpindah tangan ke orang luar.

Pola pengusahaan wisma di kompleks pelacuran Dolly ini ada dua macam, yakni yang dimiliki sendiri dan sekaligus bertindak sebagai germo, serta dengan cara kontak dengan pemilik wisma. Cara kontrak-mengontrak ini pun bermacam-macam, ada yang membayar harian, ada yang bulanan, bahkan ada yang kontan sekaligus menurut lama kontrak yang diperjanjikan. ${ }^{8}$ Namun, sebelum itu, ada baiknya dilihat dulu jumlah wisma yang ada di kompleks pelacuran ini yang terbagi ke dalam tiga rukun warga (RW).

Ternyata dari sekian banyak wisma yang bertebaran di kompleks pelacuran Dolly pada umumnya berstatus kontrak. Biaya kontrak ini berkisar antara Rp. 750.000,00 setiap bulan tergantung dari besar dan mewahnya bangunan wisma itu. Namun, kebanyakan biaya kontrak di daerah kompleks pelacuran ini adalah sebesar Rp. 3.000.000,00 sampai dengan Rp. 4.500.000,00 setiap bulan. Semakin mewah dan megah bangunan serta desain

${ }^{8}$ Kartono, Papi atau Germo, Wawancara, Surabaya, 22 Mei 2007.

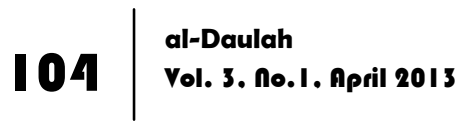


interiornya, semakin mahal pula biaya kontraknya. Jumlah kamar juga turut ikut mempengaruhi. Semakin ke tengah letaknya, harga kontrak semakin mahal. Tetapi pada umumnya daerah yang dinilai strategis adalah daerah sebelah ujung utara. Maka, germo yang berada di sebelah utara merasa diuntungkan dengan letak wismanya, karena para tamu yang datang akan terlebih dahulu singgah di wismanya.

Biaya kontrak ini bisa dibayar perhari. Jadi setiap malam pemilik rumah mendatangi wisma tersebut untuk mengambil setoran kontrak dari penyewa. Kontrak inipun bisa dibayar perbulan sekaligus, atau langsung menurut lamanya kontrak yang disepakati. Biasanya dalam mengontrak wisma ini termasuk tempat tidur, bantal, guling, lemari pakaian, serta kursi-kursi tamu di setiap kamar.

Wisma-wisma di daerah kompleks pelacuran ini semuanya dilengkapi dengan sebuah bar, botol minuman diletakkan rapi di dinding beralaskan cermin dan dihiasi lampu warna warni. Bar ini ada yang lebar, dan ada juga yang tak berlampu besar, tergantung besar kecilnya ruangan wisma yang tersedia.

Sebelum masuk ke dalam kamar biasanya telah disediakan handuk kecil sebanyak 2 buah, atau bisa juga sang pelacur yang mengambilkannya kemudian membawanya ke kamar. Atau bisa pula pelayan yang mengambilnya pada saat sang tamu berada di dalam kamar. Handuk kecil itu di kompleks pelacuran ini biasa disebut "SB" singkatan untuk "serbet". Yang mana kamar-kamar tersebut ada yang dilengkapi dengan kamar mandi dengan shower , dan ada yang hanya dilengkapi dengan bak kecil yang dipisahkan dari tempat tidur oleh sebuah tembok setinggi setengah meter. Fasilitas ini sesuai dengan kondisi wismanya.

Selain fasilitas di atas, sang germo telah mengatur sistem penempatan pelacur di dalam wisma kompleks pelacuran "Dolly", yang diantaranya: 
1. Menempatkan anak buah pada tempat duduk khusus, tanpa memperbolehkan meninggalkan tempat duduk itu bila tidak diajak oleh tamu untuk "masuk" kamar.

2. Menempatkan anak buah pada tempat duduk khusus, dengan memperbolehkan anak buah meninggalkan tempat duduk itu untuk mendatangi serta merayu "tamu".

3. Tidak menyediakan tempat duduk khusus, tersebar di kursi-kursi tamu yang ada di dalam wisma.

Menghadapi masalah kesehatan di kalangan pelacur di kompleks pelacuran Dolly, khususnya pencegahan pada penyakit kelamin, oleh pihak pemerintah daerah Surabaya diadakan penyuntikan massal seminggu sekali. Dengan mengumpulkan para pelacur beberapa wisma di suatu wisma tertentu. Biaya penyuntikan ini sebesar Rp. $100.000,00 .{ }^{9}$

Kamtib (keamanan dan ketertiban) di daerah Dolly nampaknya cukup terjamin. Boleh dikatakan tak ada kejadian penodongan, penjambretan dan sebagainya. Tetapi, sebagaimana lazimnya di daerah hitam, kompleks pelacuran ini juga dipenuhi oleh "harimau-harimau" yang siap menerkam siapa saja yang sifatnya "meninggikan" diri. Daerah Dolly dipadati oleh "gabungan anak-anak liar" yang setiap saat siap sedia memberikan hadiah "bogem" bagi pengunjung yang sok jagoan dan merusak keamanan daerah ini.

Gali (gabungan anak liar) yang biasa disebut "preman" ini ada dua orang yang menjadi penguasa Dwi Tunggal di daerah Dolly, karena tempat tinggal mereka di kampung tetangga kompleks pelacuran dolly. Yang mana pada setiap bulannya mereka mendapatkan gaji sebesar Rp. 15.000 .00 perwisma. Yang dalam sebulan tidak kurang dari Rp. 300.000 .00 yang dikumpulkannya. Di samping itu setiap wisma yang dikuasainya juga menyediakan jatah minuman bir 2 botol per minggu, selain itu preman-preman 
tersebut pagi harinya mereka kerja di toko onderdil mobil di bilangan kranggan. ${ }^{10}$

Keamanan dan ketertiban kompleks pelacuran ini lebih banyak berada di tangan orang tersebut. Selain itu ditunjang juga oleh kehadiran reserse kriminal dari komando wilayah kepolisian 101 kota Surabaya. Juga reserse dari koresta II Surabaya selatan serta kosekta II - 02 Sawahan, yang sering melakukan pengawasan di daerah ini. kecuali dari itu di ujung utara kompleks pelacuran ini terdapat sebuah pos polisi yang menangani masalah keamanan daerah Dolly dan sekitarnya. Pos ini juga ditempati oleh hansip, rukun warga setempat. Hansip-hansip ini setiap malam melakukan kontrol 2 kali yaitu pukul 24.00 dan 01.30. kalau pada saat dilakukan kontrol masih terdapat tamu di dalam kamar, kepadanya dikenakan uang kontrol sebesar Rp. 15.000,00 dan biasanya dibayar lebih dulu oleh germonya, yang kemudian dimintakan oleh tamunya. ${ }^{11}$

Pelaksanaan kontrol ini dilakukan oleh tiga atau empat orang hansip yang diikuti anggota ABRI warga setempat berpakaian preman 1 sampai 3 orang. Anggota ABRI yang ikut kontrol ini, disiapkan untuk menghadapi teman-teman oknum ABRI yang mungkin mengacau karena mabuk. Sebenarnya disetiap wisma sudah terpampang tulisan di atas seng bercat putih berukuran $20 \mathrm{x}$ $30 \mathrm{~cm}$, dengan huruf warna merah; "anggota ABRI dilarang masuk ke tempat ini". RDG.Menhankam/Pangab.Not/628/1978. Tetapi rupanya instruksi ini tidak berpengaruh terhadap beberapa oknum ABRI. Bahkan ada beberapa oknum ABRI menjadi backing para germo dalam menjaga wismanya dari gangguan pengunjung. Untuk itu mereka mendapat imbalan honor setiap bulan tak kurang dari Rp. 30.000,00. Para oknum ABRI yang sering mangkal di daerah Dolly mempunyai hubungan baik dengan penguasa preman setempat bahkan terjalin hubungan persahabatan dan penuh toleransi.

\footnotetext{
${ }^{10}$ Hans Lumintung, Departemen Litbang Abdi Asih, Wawancara, Surabaya, 29 Maret 2007.

"' Kartono, Papi atau Germo, Wawancara, Surabaya, 22 Mei 2007.
} 
Begitulah gambaran umum mengenai keamanan dan ketertiban daerah Dolly, yang mana mata para "petugas kamtib" tak resmi itu selamanya mengawasi pengunjung. Pulau yang aman, tetapi penuh ancaman.

\section{Proses Pelacuran Anak di Lokalisasi Dolly}

Pada hakekatnya pelacuran yang sedang marak kali ini tidaklah asing bagi semua orang. Karena menurut mereka tidak ada pekerjaan yang lebih mudah dikerjakan dengan hasil finansial yang menjanjikan kecuali pelacuran. Namun, bagi anak-anak yang secara psikologis hanya punya keinginan untuk berfantasi dan ekspresi dalam permainan adalah mengherankan dan menakjubkan jika anak-anak terlihat dalam lubang prostitusi dengan tujuan mengais uang yang dapat membahayakan keselamatan. Kenyataan inilah yang sudah semestinya terpikirkan oleh semua orang karena anak secara legal formal dilindungi oleh pemerintah dari berbagai jenis eksploitasi seksual apalagi terlibat dalam kubangan pelacuran.

Dari penelitian yang ada, peneliti dapat ambil konklusi bahwa anak-anak yang terlibat dalam pelacuran di lokalisasi Dolly ternyata tidak dikategorikan sebagai perbuatan yang natural. Dalam artian, mereka melakukan kegiatan prostitusi bukan dari kemauan dan keinginannya melainkan lebih banyak yang mengalami penipuan, kebohongan dan ancaman dari pihak lain yang sengaja ingin mengambil keuntungan.

Manusia secara fitrah tidak pernah dilahirkan langsung menjadi pelacur yang sungguh sangat ironis dikarenakan selalu mendapat stigma negatif dari masyarakat. Kondisi ini sesungguhnya sangat memberatkan baginya, apalagi dengan terpinggirkannya dia dari lingkaran masyarakat yang normal. Dengan demikian, lahirnya pelacuran di atas muka bumi ini bersamaan lahirnya kondisi sosial diskriminatif yang selalu melingkupinya. 


\section{Pelacuran Anak di Lokalisasi Dolly dalam Perspektif Hukum} Pidana Islam

Anak kecil adalah anak yang belum mencapai umur baligh, belum mukallaf. Anak kecil ini dibagi dua macam, yaitu: mumayyiz dan ghair mumayyiz.12 Mumayyiz adalah anak yang sudah dapat membedakan mana yang baik dan mana yang buruk, mana yang salah dan mana yang benar, yang mudharat dan yang bermanfaat. ${ }^{13}$ Ghair mumayyiz: anak-anak yang tidak cakap dalam dalam proses pendayagunaan pikiran dalam merespon kondisi di sekelilingnya. ${ }^{14}$

Dalam hukum pidana Islam dikenal dengan istilah kekuatan berpikir dan kebebasan dalam berkehendak sebagai prasyarat orang yang sudah selayaknya menerima kewajiban-kewajiban baik yang berhubungan dengan realitas ketuhanan maupun realitas kemanusiaan dalam bentuk pertanggungjawaban secara pidana. ${ }^{15}$ Namun yang terjadi adalah terjadinya perbedaan kemampuan oleh setiap anak yang kemudian memberikan banyak ruang interpretasi. Oleh karena itu, para ulama membagi fase kehidupan anak menjadi tiga fase sebagai berikut:

Pertama, Masa tak mampu berfikir, yaitu fase waktu yang dilalui oleh anak sejak dilahirkan sampai berakhir pada usia 7 (tujuh) tahun; pada fase masa ini seorang anak disebut "anak belum tamyiz". ${ }^{16}$ Namun harus dimengerti bahwa regulasi ini hanya diberlakukan dengan asumsi umum yang dapat diterapkan oleh setiap orang tanpa harus menafikan kenyataan ada banyaknya anak yang punya kemampuan berpikir walaupun masih dalam umur 7 (tujuh) tahun.

Dengan begitu, perbuatan anak ini yang masih dalam katagori ghoir mumayyiz tidak menerima beban kewajiban melainkan hanya sebuah bentuk pertanggungjawaban andaikata

\footnotetext{
12 M. Abdul Mujieb, dkk, Kamus Istilah Fiqh, (Jakarta: Pustaka Firdaus, 1994), 20.

${ }^{13}$ Ibid., 223.

${ }^{14}$ Marsum, Jinayat (Hukum Pdana Islam), (Yogyakarta: FH UII, 1984), 178.

${ }^{15}$ A. Hanafi, Asas-Asas Hukum Pidana Islam, (Jakarta: Bulan Bintang, 1993), 368.

${ }^{16} \mathrm{lbid} ., 365$.
} 
anak ini membuat kerusakan yang diderita orang lain. Maka dengan tegas hukum wad'i memberikan sanksi berupa ganti rugi. ${ }^{17}$ Dengan kata lain perbuatan anak pada masa ini tidak dianggap sebagai tindakan hukum jika dihubungkan dengan realitas vertikal namun dapat dijadikan perbuatan hukum jika tindakan ini bertalian dengan hak orang lain.

Lebih ringkasnya, seseorang punya hak dan kewajiban secara sempurna di hadapan Tuhan dan sesama manusia jika dia memiliki kapabilitas untuk menerima kewajiban (ahliyyah al-wujub) dan kapabilitas dalam menjalankan (ahliyyah al-'ada') yang dijadikan sebagai prasyarat tindak pidana. ${ }^{18}$

Kedua, fase mampu berpikir lemah; yaitu fase masa yang dimulai oleh anak sejak usia 7 (tujuh) tahun sampai mencapai kedewasaan (baligh). Kebanyakan ulama berpendapat bahwa anak sudah mencapai baligh pada usia 15 (lima belas) tahun. Imam Abu Hanifah membatasi sampai 18 (delapan belas) tahun pada masa ini kalau si anak melakukan jarimah, anak tersebut tidak dikenai hukuman pidana melainkan hanya hukuman pengajaran. ${ }^{19}$ Anak pada masa ini disebut mumayyiz.

Pada masa ini anak tersebut telah memiliki kemampuan untuk mempunyai dan menanggung hak (ahliyyatul wujub) secara sempurna. Sedangkan aliyyatul 'ada' (kemampuan melakukan) anak tersebut juga sudah memiliki akal yang telah berfungsi untuk mengetahui sesuatu, tetapi masih kurang (naqis), sehingga ahliyyatul 'ada' baginya juga belum sempurna. Karena itu ia dianggap sah untuk melakukan hak dan membuat transaksi, tetapi hanya untuk hal-hal yang bermanfaat (positif) saja. ${ }^{20}$

Ketiga, fase mampu berpikir penuh; yaitu sejak seorang anak telah mencapai masa cakap bertindak (rushd); atau sesudah ia mencapai usia 15 (lima belas) tahun, atau 18 (delapan belas) tahun

\footnotetext{
${ }^{17}$ Marsum, Jinayat. 178.

18 Muhammad Abu Zahrah, Ushul Al-Fiqh. terj. Saefullah Ma'shum, dkk. (Jakarta: Pustaka Firdaus, t.t.), 508-509.

${ }^{19}$ Marsum, Jinayat. 179.

${ }^{20}$ Muhammad Abu Zahrah, Fiqh. 509.
} 
atau 19 (sembilan belas) tahun menurut perbedaan pendapat dikalangan para ulama, pada masa ini kalau si anak melakukan jarimah ia dikenakan pertanggunga jawab pidana. ${ }^{21}$ Anak pada masa ini disebut dengan baligh.

Pada masa inilah seseorang mampu menggabungkan antara seseorang dikenai seluruh taklif (beban) keagamaan, seperti taklif menunaikan shalat, puasa, haji dan lain-lainnya. Segala perbuatannya dikenai hukum, seperti bila ia membunuh ia akan diqishash, bila berzina akan dihukum had, bila menuduh zina tanpa bukti akan didera delapan puluh kali dan seterusnya. Dia akan dikenakan hukuman dan siksa menurut syara' apabila melanggar atau mengerjakan hal-hal yang akan mendatangkan hukuman dan siksa itu. Sedangkan dalam masalah akad transaksi dan penggunaan harta, kalau dia dipandang tidak cakap maka para ulama sepakat anak itu tidak diperbolehkan. ${ }^{22}$

Jadi yang disebut anak di bawah umur menurut hukum Islam adalah anak yang belum mencapai baligh atau mencapai usia 15 (lima belas) tahun (pendapat jumhur ulama). Jika menurut perhitungan umur yang ditetapkan ulama anak tersebut mengalami gangguan mental maka anak tersebut tidak dikenai takli>f. Hal ini sejalan dengan sabda Rasulullah saw:23

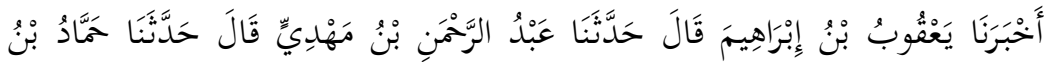

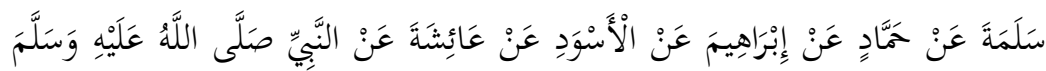

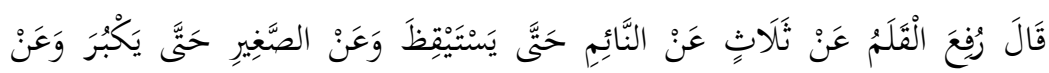

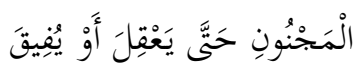

Implikasi dari syarat pertama ini adalah anak kecil, orang gila, orang lupa, dan orang tidur tidak dikenakan taklif karena

\footnotetext{
${ }^{21}$ Marsum, Jinayat. 179.

${ }^{22}$ Muhammad Abu Zahrah, Figh. 51 I.

${ }^{23}$ CD Hadits Kutubus Sittah, Sunan An-Nasa'i, Kitab Ath-Thalaq, No. 3378
} 
dalam keadaan atau status mereka masing-masing tidak atau belum mampu memahami dalil syara' ${ }^{24}$

Perbuatan seseorang baru bisa dikenai taklif apabila orang tersebut telah memenuhi dua syarat yaitu:

1. Adanya pemahaman dengan maksimal terhadap tuntutan hukum yang terkandung dalam pedoman hidup umat Islam. Itu semua dikarenakan semua perintah dan larangan dalam ajaran Islam tertulis dalam al-Qur'an dan andaikata dia tidak memahami pesan-pesan kitab suci baik secara tekstual maupun kontekstual, maka sangat tidak mencerminkan terhadap kebijaksanaan jika taklif masih tetap dibebankan kepada orang tersebut. ${ }^{25}$

Kemampuan untuk memahami taklif tersebut hanya bisa dicapai melalui akal manusia, karena akallah yang bisa mengetahui taklif itu harus dilaksanakan atau ditinggalkan. Akan tetapi karena akal adalah sesuatu yang abstrak dan sulit diukur, serta berbeda antara seseorang dengan yang lainnya, maka syara' menentukan patokan dasar, yang menjadi indikasi yang konkrit (jelas) dalam menentukan seseorang telah berakal atau belum. Indikasi itu adalah balighnya seseorang. Penentu seseorang telah baligh itu ditandai dengan keluarnya haid pertama bagi wanita dan keluarnya mani bagi pria melalui mimpi yang pertama kali. ${ }^{26}$

2. Kapabilitas dalam tindakan hukum. Dalam artian seseorang harus cakap bertindak hukum, yang dalam ushul fiqh disebut dengan ahliyyah. Artinya apabila seseorang belum atau tidak cakap bertindak hukum, maka seluruh perbuatan yang ia lakukan belum atau tidak bisa dipertanggung jawabkan. Oleh sebab itu anak kecil yang belum baligh, belum cakap bertindak hukum dan tidak dikenakan tuntutan syara' ${ }^{27}$

\footnotetext{
${ }^{24}$ Nasrun Haroen, Ushul Figh I, (Jakarta: Logos Wacana IImu, 1997), 306.

${ }^{25} \mathrm{Ibid}$., 306.

${ }^{26} \mathrm{lbid}$., 307

${ }^{27} \mathrm{Ibid}$., 307.
} 
Dalam hukum pidana Islam, aktifitas pelacuran sangat sulit dicarikan padanan konsep kecuali dikategorikan dengan zina atau jarimah yang berkaitan dengan seksual atau hubungan kelamin yang dilarang, masuk ke dalam kategori jarimah zina. ${ }^{28}$

Definisi lain yang lebih komprehensif seperti yang tersurat dalam kitab sebagai berikut:

Zina adalah hubungan seksual yang dilakukan seorang lakilaki secara sadar terhadap seorang wanita yang disertai nafsu seksual dan diantara mereka tidak atau belum ada hubungan kepemilikan atau tuan dan hambanya yang menyerupainya serta yang menyebabkan adanya hubungan kekeluargaan, nasab dan persusuan. ${ }^{29}$

Dari definisi zina di atas maka suatu perbuatan dapat dikatakan zina apabila sudah memenuhi dua unsur yaitu :

a. Adanya persetubuhan antara orang yang berbeda jenis kelaminnya; dan

b. Tidak adanya keserupaan atau kekeliruan dalam perbuatan seks. ${ }^{30}$

Menurut A. Dzajuli yang mengutip Ulama Malikiyah, zina adalah persetubuhan yang dilakukan oleh seorang laki-laki mukallaf terhadap wanita yang bukan miliknya dilakukan dengan sengaja. Adapun ulama Syafi'iyyah, masih dari sumber yang sama, mendefinisikan zina adalah memasukkan dhakar ke dalam farj yang haram dengan tidak shubhat dan secara naluri memuaskan hawa nafsu. ${ }^{31}$

Untuk keterpaksaan yang disebabkan oleh subyek secara langsung, hukum Islam yang diwakili seluruh ulama mazhab bersepakat tidak menjatuhkan sanksi kepada pelaku prostitusi jika

\footnotetext{
${ }^{28}$ Al- Jurjani, At-Ta'rifat, (Beirut: Darul Kutub IImiyah, 2009), 101 .

${ }^{29}$ Abdul Rahman Al-Jaziri, Kitab al-Figh ala al-Madhahib Al-'Arba'ah, Juz V, (Beirut Lubnan: Dar alKutub al-'Ilmiyah, 1990), 49.

30 Masjfuk Zuhdi, Masail Fiqhiyah : Kapita Selekta Hukum Islam, (Jakarta: Haji Masagung, 1988), 34.

${ }^{31}$ A. Dzajuli, Fiqh Jinayah (Upaya Menanggulangi Kejahatan dalam Islam), cet. ke-2, (Jakarta: PT Raja Grafindo Persada, 1997), 35.
} 
pemaksa merupakan seseorang yang punya kekuasaan secara mutlak (sultan). Namun jika pemaksaan dilakukan oleh selain pihak penguasa, maka hanya ulama Hanafiyah yang menyatakan perlu adanya hukuman bagi pelaku prostitusi dikarenakan adanya asumsi bahwa pemaksaan yang dilakukan oleh selain penguasa masih berpotensi bagi pelaku untuk menghindar. Sehingga hanya kemauan dan kerelaanlah yang mendorong terjadinya pelacuran tersebut. Lebih lebih menurut ulama Syafi'iyyah, seseorang yang memaksa untuk mengajak melakukan hubungan seksual di luar pernikahan yang sah juga diberi hukuman (had) tanpa kompromi. ${ }^{32}$

Selanjutnya untuk menganalisis perbuatan tidak senonoh yang dikarenakan oleh modus penipuan yang akhir-akhir ini lebih marak terjadi pada anak-anak yang kehidupannya di bawah standar hidup layak, maka tentu tidak semudah memberikan solusi terhadap permasalahan di atas. Namun secara umum penulis dapat katakan bahwa sanksi tetap dijatuhkan pada pelaku prostitusi bukan terhadap orang yang melakukan penipuan dengan asumsi bahwa hanya orang yang melakukan suatu perbuatan yang dituntut untuk bertanggungjawab. Dan perintah untuk mawas diri dengan melakukan bayan terhadap apapun adalah merupakan kewajiban bagi setiap orang Islam Pendapat ini didasarkan pada kaidah fiqh berupa:

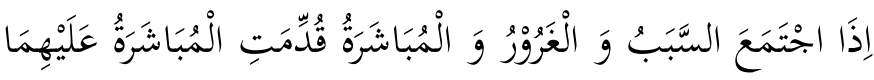

"Jika dalam suatu kejadian berkumpul adanya faktor penyebab, penipuan dan eksekusi, maka yang didahulukan untuk bertanggungjawab adalah orang yang mengekskusi". ${ }^{33}$

Namun andaikata setelah adanya penipuan terjadi pemaksaan terhadap anak untuk melakukan kegiatan prostitusi yang tidak bisa dihindarkan, menurut hemat penulis, hukuman yang setimpal dari pihak yang berwenang harus diarahkan pada orang yang memaksa dan menyebabkan timbulnya kemaksiatan

\footnotetext{
${ }^{32}$ Abdurrohman Jaziri, Kitab al-Fiqh 'Ala al-Madzahib al-'Arba'ah, Juz V, 96

${ }^{33}$ Abdullah Bin Sulaiman, al-Mawahib al-Saniyyah, 274.
} 
tersebut. Pendapat ini bisa dikatagorikan sebagai exception dari kaidah figh di atas. ${ }^{34}$

Lebih lanjut, perbuatan di atas sudah sejak dulu dipraktekkan dalam masa jahiliyah dan dikatagorikan sebagai sesuatu yang diharamkan oleh agama seperti yang tersurat dalam firman Allah dalam surat an-Nur ayat 33:

"...Dan janganlah kamu paksa budak-budak wanitamu untuk melakukan pelacuran padahal mereka menginginkan kesucian, karena kamu hendak mencari keuntungan duniawi. Dan barangsiapa yang memaksa mereka, maka sesungguhnya Allah adalah maha pengampun lagi Maha Penyayang (terhadap mereka yang dipaksa) sesudah mereka dipaksa itu".

Adapun perbuatan pelacuran yang disebabkan oleh kondisi yang tidak memungkinkan berbuat sesuatu yang terjastifikasi "sopan dan normal" dalam tatanan sosial, baik faktor ekonomi, pendidikan dan sebagainya, maka hemat penulis perbuatan tersebut sah-sah saja dilakukan dalam batas-batas tertentu oleh anak yang misalnya dikarenakan faktor ekonomi akan mengalami kondisi darurat. Darurat di sini diartikan sebagai kondisi yang akan menghantarkan anak pada jurang kematian. Pendapat ini didasarkan pada kaidah fiqh sebagai berikut:

"Kondisi darurat akan membolehkan seseorang melakukan sesuatu yang dilarang oleh agama"35

Sedangkan kaidah fiqh tersebut disandarkan pada firman Tuhan dalam QS. al-Hajj: 78 dan QS. al-Baqarah: 185.

Kondisi di atas, sangat tepat kalau diilustrasikan sebagai pelacuran ditinjau dari segi pelayanan jasa terhadap orang lain tanpa adanya perpindahan kepemilikan (isti'jar) yang kemudian menimbulkan friksi antara sesama ulama mazhab tentang bagaimana status hukum dan cara memperlakukannya. Dengan demikian, pelacuran yang selama ini dilakukan oleh anak-anak yang selalu mendapat stigma dosa sosial oleh seluruh masyarakat

\footnotetext{
${ }^{34}$ Ibid., 277.

35 Ibid., | | 4- | 16.
} 
seharusnya mendapat reaksi yang proporsional. Itu semua dikarenakan pelacuran tidak selamanya merupakan bentuk tindakan pidana yang memberikan mandat kepada masyarakat untuk lebih banyak mengambil tindakan-tindakan prefentif karena dianggap sebagai bentuk penghianatan terhadap kesepakatan sosial namun ada juga yang hanya merupakan katagorisasi dosa yang kesalahannya lebih banyak mencederahi terhadap domain relasi vertikal.

Adapun pelacuran sebagai media pelayanan jasa tanpa adanya perpindahan status kepemilikan sangatlah variatif jika dihubungkan dengan pendapat ulama mazhab:

1. Ulama Hanafiyah berpendapat bahwa pelacuran dengan model pelayanan jasa tidaklah merupakan perbuatan tindak pidana yang layak mendapatkan hukuman (had) namun hanya merupakan perbuatan dosa yang mengakibatkan adanya $t a^{\prime} z i r^{36}$ dari pihak yang berwenang. Pendapat ini didasarkan pada suatu cerita tentang adanya perbuatan zina yang dilakukan oleh seorang perempuan dalam kondisi memprihatinkan dikarenakan tidak ada makanan dan minuman yang dapat dibuat mengganjal perutnya. Kemudian seorang lelaki yang dimintahinya tidak memberikan susu kecuali dengan adanya pelayanan jasa yang harus diberikan berupa pemberian kenikmatan seksual pada masa pemerintahan khalifah Umar ibn Khattab. Namun sungguh mengejutkan kebijakan yang diambil oleh khalifah ternyata tidak berupa pemberian hukuman kepada pelaku zina yang konon sampai saat ini masih menjadi dosa sosial dan perbuatan itu dianggap sebagai praktek isti'jar. ${ }^{37}$

2. Ulama Malikiyah, Syafi'iyah, Hanabilah berpendapat bahwa pelacuran sebagai media pelayanan jasa tetap teridentifikasi

\footnotetext{
${ }^{36}$ Lihat Abdurrahman al-Jaziri dalam Kitab al-Figh 'Ala al-Madhahib al-'Arba'ah, Juz V, h. 9 yang mendifinisikan ta'zir sebagai hukuman yang diberikan oleh pihak yang berwenang terhadap perbuatan menyimpang yang tidak diganjar dengan had dan kaffarah hanya bertujuan untuk memberikan pendidikan agar berperilaku baik.

${ }^{37}$ Abdurrahman al-Jaziri, Kitab al-Fiqh 'Ala al-Madhahib al-'Arba'ah, Juz V, 96.
}

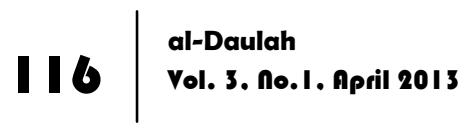


sebagai tindak pidana yang kedua pelakunya harus mendapatkan hukuman (had). Karena alat pelayanan jasa yang berupa kenikmatan seksual (kemaluan pria dan wanita) tidak dapat digunakan dalam transaksi ijarah. Dengan begitu, alasan pelayanan jasa tidak dapat menggugurkan hukum pidana. ${ }^{38}$

Tereksklusinya Hanafiyah dari pendapat umum para Imam Mazhab dapat difahami sebagai bentuk keberanian dalam keberpihakan dalam pengetahuan yang harus diposisikan secara proporsional. Karena pendapat ini berpegang teguh pada kemaslahatan manusia yang menjadi tujuan diberlakukannya hukum Islam.

Kembali pada persoalan di atas bahwa pelacuran sebagai tindakan asusila tersebut dilakukan oleh anak yang nota bene-nya belum dapat dikatagorisasi sebagai manusia bewasa (mukallaf) yang sudah saatnya menerima beban kwajiban dan larangan dalam syariat Islam.

Dalam perspektif hukum pidana Islam ternyata tidak mengalami perbedaan pendapat dalam merespon kegiatan asusila tersebut. Menurut Ulama Mazhab Empat, hukum pidana ( $h\} a d$ ) hanya diberikan kepada pelaku yang sudah dewasa bukan pelaku yang masih tergolong anak-anak. Itu semua didasarkan pada kenyataan hukum Islam yang selalu dikaitkan dengan klausulklausul dewasa; baligh, berpikir dan sebagainya. ${ }^{39}$

Dengan memperhatikan kenyataan di atas bahwa yang melakukan perbuatan pelacuran adalah anak-anak dengan adanya faktor maupun tidak, penulis dapat simpulkan tentang tidak adanya hukuman tertentu dari pihak yang berwenang selama tidak merugikan orang lain.

Adapun pihak-pihak yang sengaja atau tidak sengaja menyebabkan terjadinya pelecehan seksual dalam pelacuran yang dialami oleh anak dalam lokalisasi Dolly dengan modus penipuan

\footnotetext{
38 Ibid., 97.

39 Ibid., 61 .
} 
dan pemaksaan seharusnya mendapat hukuman yang setimpal dari pemerintah. Karena Tuhan dengan tegas menyatakan perbuatan tersebut sebagai perbuatan yang menistakan manusia yang bebas dari perbudakan dan representasi dari nalar jahiliyah..

Walaupun begitu, sudah menjadi kewajiban orang tua atau yang mengantikannya untuk menjaga anak agar tidak terjerumus dalam jurang kemaksiatan. Itu semua harus dilakukan dengan pertimbangan akan adanya kebiasaan yang akan menjadi pembimbing dan ahirnya menjadi penentu dalam perbuatan prostitusi.

Kegiatan pencegahan tersebut dapat diatasi oleh orang tua jika ada kesadaran tentang kewajiban orang tua terhadap anak tidak hanya dalam kemaslahatan rohani, namun yang lebih penting adalah mengusahakan terwujudnya kemaslahatan anak secara jasmani. Dikarenakan kemaslahatan dalam aspek materi dapat mendorong anak untuk memahami agama dengan benar dan dapat mencari pengetahuan secara paripurna.

\section{Pelacuran Anak di Lokalisasi Dolly dalam Perspektif Kitab Undang-Undang Hukum Pidana}

Sebenarnya dalam aturan-aturan yang berlaku di negara Indonesia, Eksploitasi seksual anak oleh orang lain sudah mendapat pencegahan secara legal baik hanya berupa Pelecehan seksual yang dialami oleh anak-anak baik yang dilakukan dengan sukarela maupun keterpaksaan atau bahkan pelecehan seksual yang terlembagakan (prostitusi). Adapun pelecehan seksual model pertama sebenarnya sudah banyak dijelaskan dalam KUHP yaitu pada pasal 287, 290 (2) dan (3), 294 (1) dan 295 (1).

Namun sebelum pembahasan isi yang termuat dalam KUHP secara tuntas dilakukan dan agar pembahasan lebih mudah dan sistematis, penulis membagi analisa anak korban pelacuran di lokalisasi Dolly menjadi dua bagian. Bagian pertama berbicara tentang usaha preventif yang dilegalkan guna merespon pelecehan seksual secara konvensional. Dan bagian yang kedua 
berorientasi pada pembahasan tentang respon peraturan terhadap praktek pelecehan seksual secara komersial.

Untuk bagian pertama, penulis merasa sangat terbantu dengan adanya pasal 287 yang membahas tentang persetubuhan dengan wanita di bawah umur 15 tahun dengan ancaman pidana penjara paling lama sembilan tahun. Adapun pada pasal 290 (2) tentang perbuatan cabul yang dilakukan oleh seseorang terhadap anak di bawah umur 15 tahun tanpa bantuan orang lain. Sedangkan ayat 3 berbicara tentang seseorang yang membujuk untuk melakukan atau membiarkan dilakukan perbuatan cabul terhadap anak di bawah 15 tahun. Lalu pasal 294 (1) tentang perbuatan cabul dengan anaknya, anak tiri, anak angkat, anak di bawah pengawasan yang belum cukup umur. Terakhir pasal 295 tentang memudahkan dilakukan perbuatan cabul oleh anaknya, anak tirinya, anak angkatnya atau anak di bawah pengawasannya yang belum cukup umur.

Sedangkan bagian kedua, sangat dipengaruhi oleh Pasal 293 (1) yang berbicara lebih banyak tentang klausul memberi atau menjanjikan uang atau barang, menyalahgunakan perbawa yang timbul dari hubungan keadaan, atau dengan penyesatan untuk melakukan atau membiarkan dilakukan perbuatan cabul terhadap anak di bawah umur. Untuk lebih jelasnya sebagai berikut:

"Barangsiapa dengan memberi atau menjanjikan uang atau barang menyalahgunakan perbawa yang timbul dari hubungan keadaan atau dengan penyesatan sengaja menggerakkan seomembiarkan dilakukan perbuatan cabul dengan dia, padahal tentang belum cukup umurnya itu diketahui atau selayaknya harus diduga, diancam dengan pidana penjara paling larang belum cukup umur dan baik tingkah lakunya, untuk melakukan atau ma lima tahun"

Selain di atas, pasal yang harus dikenakan dalam menggantisipasi maraknya pelacuran anak di bawah umur adalah pasal 297 KUHP yang berbicara tentang segala perbuatan membawa (menyerahkan) seorang perempuan atau laki-laki yang masih dalam usia belum dewasa ke dalam praktek pelacuran 
harus mendapatkan pidana penjara selama-lamanya enam tahun. Untuk lebih jelasnya sebagai berikut:

"Perdagangan wanita dan perdagangan anak laki-laki yang belum cukup umur diancam dengan pidana penjara paling lama enam tahun"

Terhadap pasal ini R. Soesilo memberikan komentar sebagai berikut :

1. Yang dimaksud dengan perniagaan atau perdagangan perempuan adalah melakukan perbuatan-perbuatan dengan maksud untuk menyerahkan perempuan guna pelacuran. Masuk pula dalam pasal ini adalah mereka yang biasanya mencari perempuan didesa-desa untuk dikirim ke kota dengan maksud tak lain akan dipergunakan untuk pelacuran.

2. Yang diancam di sini tidak hanya perdagangan wanita di bawah umur tetapi juga anak laki-laki di bawah umur. ${ }^{40}$

Untuk melindungi kepentingan anak, ternyata pemerintah tidak hanya berhenti pada KUHP semata. Misalnya dalam UUPA No. 23 2002, pasal 13 ayat 1 b disebutkan bahwa anak selama dalam perwalian anak wajib mendapatkan perlindungan dari perlakuan eksploitasi. Pengertian eksploitasi disini seperti dalam penjelasan berarti tindakan atau perbuatan memperalat, memanfaatkan atau memeras anak untuk memperoleh kepentingan pribadi, keluarga atau golongan dengan cara eksploitasi seksual atau yang lain. Untuk lebih jelasnya sebagai berikut :

"Setiap anak selama dalam pengasuhan orang tua, wali, atau pihak lain manapun yang bertanggungjawab atas pengasuhan, berhak mendapat perlindungan dari perlakuan eksploitasi baik baik ekonomi maupun seksual".

Selain dari pada itu, jika ternyata masih banyak orang yang melakukan eksploitasi seksual dengan menjerumuskannya dalam dunia pelacuran, maka dia harus mendapatkan pidana penjara

${ }^{40}$ R. Soesilo, KUHP dan Penjelasannya, 217.

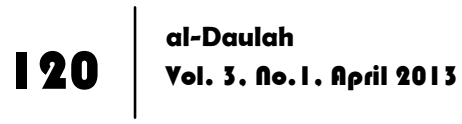


paling lama lima tahun. Penjelasan ini didapat dari pasal 78 yang berbunyi :

"Setiap orang yang mengetahui dan sengaja membiarkan anak dalam situasi darurat sebagaimana dimaksud dalam pasal 60, anak yang berhadapan dengan hukum, anak dari kelompok minoritas dan terisolasi, anak yang tereksploitasi secara ekonomi dan atau seksual, anak yang diperdagangkan, padahal anak tersebut memerlukan pertolongan dan harus dibantu, dipidana dengan pidana penjara paling lama 5 tahun atau denda paling banyak seratus juta rupiah". Ketentuan dalam pasal 296 KUHP ini dimaksudkan untuk dapat memberantas orang-orang yang memberantas orang-orang yang mengadakan tempat-tempat pelacuran yang banyak terdapat dikota-kota besar. Apabila orang itu memiliki usaha pelacuran dan merupakan mata pencahariannya maka orang tersebut dapat dihukum sesuai dengan pasal 296 KUHP.

Mengenai rumusan ini $R$. Soesilo memberikan komentar sebagai berikut :

1. Pasal tersebut di atas gunanya untuk memberantas orangorang yang mengadakan bordil-bordil atau tempat-tempat pelacurang yang banyak terdapat dikota-kota besar.

2. Supaya dapat dipidana, maka harus dapat dibuktikan bahwa perbuatan tersebut menjadi mata pencahariannya.

3. Perbuatan cabul termasuk di dalamnya adalah persetubuhan.

4. Yang dikenakan dalam pasal tersebut adalah orang yang menyediakan rumah atau kamarnya kepada perempuan atau laki-laki untuk bersetubuh atau melepaskan nafsu kelaminnya. ${ }^{41}$

Pasal 297 KUHP :

"Memperniagakan perempuan dan memperniagakan laki-laki yang belum dewasa, dihukum penjara selama-lamanya enam tahun".42

Yang dimaksud dengan perdagangan didalam pasal 297 KUHP adalah melakukan perbuatan-perbuatan dengan maksud

41 lbid.

42 lbid. 
menyerahkan perempuan di bawah umur yang digunakan sebagai pelacur.

Tidak berhenti di situ, pemerintah dengan jelas menutup akses pelacuran anak sebagai bentuk perdagangan anak seperti yang tercakup dalam UU No.13, 2003 pasal 74 ayat 1 dan $2 b$ tentang ketenagakerjaan yang berbunyi :

Siapa pun dilarang mempekerjakan dan melibatkan anak pada pekerjaan yang terburuk.

1. Segala pekerjaan yang memanfaatkan, menyediakan atau menawarkan anak untuk pelacuran, produksi pornografi, pertunjukan porno atau perjudian.

Dari sekian peraturan yang diberlakukan, penulis dapat simpulkan bahwa anak pada dasarnya punya hak yang harus dipenuhi orang tua, masyarakat, pemerintah untuk mendapatkan perlindungan dari segala bentuk eksploitasi demi tercapainya kehidupan yang layak secara rohani, jasmani dan sosial. Pelacuran yang dialami oleh anak-anak yang kebetulan berlokasi di lokalisasi Dolly adalah bentuk perdagangan manusia atau trafiking.

Namun jika masih ada pihak-pihak yang tidak mengindahkannya, maka anak atau orang lain harus melakukan tuntutan dengan pidana penjara sebagai yang tertera dalam peraturan.

\section{Langkah-langkah Advokatif terhadap Pelacuran Anak di Lokalisasi Dolly}

Advokasi adalah proses untuk membantu masyarakat untuk memahami dan mengerti akan hak-haknya dengan jalan usaha menuntut hak dan mempertahankannya.

Terdapat beberapa asumsi advokasi: Asumsi pertama dalam advokasi adalah masyarakat mempunyai hak dan hak itu harus dipenuhi dan dipertahankan. Dengan begitu, advokasi merupakan rangkaian proses yang menyangkut upaya perlindungan hak-hak dasar warga Negara. Asumsi kedua adalah bahwa kegiatan ini didedikasikan meningkatkan taraf dan kualitas hidup warga 
Negara. Hal ini tidak saja menyangkut peningkatan kesejahteraan tetapi juga kompetensi dan mentalitas yang menjadi kebutuhan dasar.

Dalam advokasi banyak dikenal varian strategi advokasi yang tentu disesuaikan dengan kasus yang dihadapi; Strategi informasi, strategi kolaborasi, dan strategi konfrontasi. Strategi informasi mengasumsikan bahwa target adalah masyarakat yang tidak cukup punya informasi untuk membuat keputusan dan bagaimana melakukan pembelaan diri. Dan strategi kedua ini berasumsi bahwa masyarakat mengetahui tentang hak dan cara membelanya secara individual. Sedangkan target strategi konfrontasi adalah minimalisasi kegagalan tatkala negoisasi dan dialog dengan pihak yang terkait menemui kesulitan.

Tujuan akhir langkah advokatif adalah melindungi hak, pemberdayaan dan meningkatkan kesejahteraan. Dengan begitu, advokasi bukanlah semata-mata reaksi sesaat, namun lebih dari itu, advokasi dijalankan penuh dengan perencanaan, pertimbangan dan kesejahteraan. ${ }^{43}$

Pelacuran anak di bawah umur salah satu permasalahan sosial yang muncul di kota-kota terutama di kota besar termasuk Surabaya. Telah banyak penelitian yang menemukan bahwa kehidupan Anak yang Dilacurkan (AyLa) adalah kehidupan yang melekat dengan kekerasan. Dalam bisnis prostitusi, kehadiran anak-anak di bawah umur bahkan menjadi komoditi yang dijadikan daya tarik khusus bagi germo untuk kepentingan ekonominya. Di lokalisasi Dolly dan Jarak menunjukkan adanya kecenderungan semakin meningkatnya jumlah pekerja seks usia muda (11-17 tahun) dan diperkirakan mencapai $10 \%$ dari jumlah pekerja seks yang ada.

Kendati sebagian masih memiliki orang tua, tetapi kadang mereka tidak merasa anak-anaknya rawan kekerasan ketika berada di jalanan. Bahkan ada sebagian orang tua yang menjadi

\footnotetext{
${ }^{43}$ Koirudin. Menuju Partai Advokasi, (LKiS Yogyakarta: Pustaka Tokoh Bangsa, 2005), 50.
}

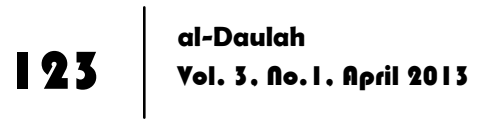


pendorong atau dengan alasan tertentu untuk memaksa anaknya turun ke jalanan atau hidup di jalanan bahkan menjadi pekerja seks di mana adanya kecenderungan budaya timur bahwa anak harus patuh kepada kehendak orang tuanya sehingga tidak jarang anak hanya menikmati 30\% dari hasil keringatnya dan 70\% sisanya diminta oleh orang tuanya. Krisis ekonomi yang terjadi di tanah air akhir-akhir ini menyebabkan berbagai macam dampak di segala bidang. Dampak ekonomi membuat anak-anak menjadi malas untuk bekerja secara normal, mereka cenderung mencari uang secara cepat dengan jalan mengamen, mengemis bahkan menjual diri. Uang pemberian masyarakat baik secara perorangan maupun kelembagaan menyebabkan anak-anak jalanan menjadi malas dan sangat tergantung.

Dari sinilah penulis tekankan bahwa sudah saatnya melakukan kegiatan advokatif sebagai solusi adanya kesenjangan antara idealitas peraturan dan realitas pelacuran anak yang semakin hari semakin banyak. Rumitnya permasalahan yang dihadapi oleh anak yang menjadi korban pelacuran di lokalisasi Dolly membuat penulis mengambil tiga tahapan advokasi. Tahapan pertama, berbicara tentang advokasi hukum dan HAM dan tahapan kedua, melakukan advokasi yang berbasis anggaran serta dilanjutkan dengan tahapan yang terahir berupa advokasi kebijakan.

Untuk melaksanakan advokasi hukum dan HAM, perlu adanya kecermatan dan keahlian dalam menghubungkan faktafakta hukum yang terjadi pada anak yang menjadi korban pelacuran dengan aturan hukum positif. Namun sebelum proses advokasi ligitasi di atas dijalankan, anak yang menjadi korban tersebut harus memberikan surat kuasa kepada orang yang melakukan advokasi. Dalam kasus ini yang dilakukan adalah dengan memberikan informasi secara detail kepada anak-anak yang menjadi korban pelacuran tentang hak-hak yang dilanggar oleh orang lain. Selanjutnya advokasi dilanjutkan dalam bentuk pendampingan dalam melaksanakan prosedur hukum acara. 
Dengan demikian, anak yang dulunya tidak mengerti tentang hakhak yang dilanggar oleh orang lain dan tidak punya keberanian dalam beracara baik dalam kasus pidana, perdata dan sebagainya tidak akan mengalami tindakan eksploitatif lagi. ${ }^{4}$

Tahapan yang kedua, adalah advokasi anggaran yang menitik beratkan pada ketepatan sasaran anggaran yang diperuntukkan untuk kemaslahatan anak korban pelacuran. Untuk menjalankan ini seseorang atau lembaga yang melakukan advokasi harus melakukan pendekatan dengan birokrasi, pengusaha dan LSM dengan target sebagai berikut; Anggaran harus bertumpu pada kepentingan anak korban pelacuran; Anggaran harus dikelola dengan hasil yang baik dan biaya rendah. ${ }^{45}$

Asumsi advokasi anggaran ini adalah sudah menjadi kenyataan tak terbantahkan bahwa secara umum bahwa menjamurnya pelacuran anak disebabkan kondisi finansial orang tua tidak memadahi dalam mewujudkan kesejahteraan anak baik secara rohani, jasmani dan sosial. Oleh karena itu, dengan adanya advokasi anggaran ini diharapkan seluruh anggaran itu di peruntukkan untuk mensejahterakan anak korban pelacuran.

Sedangkan tahap yang terakhir, adalah advokasi kebijakan dengan pengertian sebagai tindakan-tindakan interventif dan tekanan yang jauh ke dalam pusat-pusat pengambilan kebijakan. Dalam advokasi ini perlu kiranya dilakukan advokasi yang berbasis isu dengan metode pelatihan, pendidikan dan sebagainya yang bertujuan untuk melindungi hak-hak dasar warga negara. Kemudian dilanjutkan dengan advokasi yang berbasis kasus dengan cara pengubahan, penggantian kebijakan yang bertujuan untuk meningkatkan kesejahteraan anak yang menjadi korban pelacuran. ${ }^{46}$

\footnotetext{
44 Ibid., 63-74.

45 lbid., 83.

46 Ibid., I0 I - 103.
} 


\section{Penutup}

Dalam perspektif hukum pidana Islam, permasalahan pelacuran anak merupakan penistaan terhadap manusia yang bebas dari perbudakan dan representasi dari nalar Jahiliyah. Sedangkan perbuatan pelacuran tersebut tidak mendapatkan hukuman atau sanksi dikarenakan anak hanya punya kapabilitas dalam kewajiban (ahliyyah al-wujub) bukan kapasitas perbuatan (ahliyyah al-'ada'). Namum pihak-pihak yang menyebabkan terjadinya pelacuran anak harus mendapat hukuman dengan asumsi telah melakukan penipuan serta pemaksaan. Adapun permasalahan pelacuran anak dalam perspektif Hukum Pidana difahami sebagai tindakan yang melanggar hak-hak dasar anak atas perlindungan dari segala jenis kegiatan eksploitatif yang mengharuskan orang yang menyebabkan terjadinya pelacuran mendapatkan hukuman sesuai dengan peraturan yang berlaku. Lebih dari itu, pelacuran anak merupakan bentuk dari perdagangan manusia atau trafficking.

Advokasi yang didedikasikan untuk anak yang menjadi prostitusi adalah pertama: advokasi litigasi dengan target anak yang hak-hak dasarnya dilanggar oleh orang lain dapat dipulihkan kembali. Kedua: advokasi anggaran dengan tujuan agar anggaran yang dikelolah oleh pemerintah dapat dialokasikan tepat kepada anak yang menjadi korban pelacuran. Ketiga: advokasi kebijakan dengan tujuan melindungi hak-hak dasar dan meningkatkan kesejahteraan anak yang menjadi korban pelacuran.

\section{Daftar Pustaka}

Asyari, S. Imam. Patologi Sosial. Surabaya: Usaha Nasional, 1983.

CD Hadits Kutubus Sittah. Sunan An-Nasa'i. Kitab Ath-Thalaq, No. 3378

Departemen Agama RI. al-Quran dan Terjemahannya. Surabaya : AlHidayah, 1998. 
Djazuli, A. Figh Jinayah (Upaya Menanggulangi Kejahatan dalam Islam). cet. ke-2, Jakarta: PT Raja Grafindo Persada, 1997.

Hanafi, A. Asas-Asas Hukum Pidana Islam. Jakarta: Bulan Bintang, 1993.

Haroen, Nasrun. Ushul Figh 1. Jakarta: Logos Wacana Ilmu, 1997.

Jarhazi (al-), Abdullah bin Sulaiman. al-Mawahib al-Saniyyah. Beirut: Dar al-Fikr, 1997.

Jawa Pos, 4 Maret, 2006

Jaziri (al-), Abdul Rahman. Kitab Al-Figh 'Ala Al-Madzahib Al'Arba'ah. Juz V. Beirut Lubnan: Dar al-Kutub al-'Ilmiyah, 1990.

Jurjani (al-), Ali bin Muhammad. At-Ta'rifat. Beirut: Darul Kutub Ilmiyah, 2009.

KhAlaf, Abdul Wahab. Ilmu Ushul Figh. Mesir: Darul Hadis, 2003.

Khalaf, Abdul Wahab. Ilmu Ushul Fiqih, terj. Faiz el-Muttaqin, Jakarta: Pustaka Amani, 2003.

Koirudin. Menuju Partai Advokasi. LKiS Yogyakarta: Pustaka Tokoh Bangsa, 2005.

Marsum. Jinayat (Hukum Pdana Islam). Yogyakarta: FH UII, 1984.

Moeljatno. KUHP: Kitab Undang-Undang Hukum Pidana. Jakarta: Bumi Aksara, 2007.

Mujieb, M. Abdul. dkk. Kamus Istilah Figh. Jakarta: Pustaka Firdaus, 1994.

Qadir, Faqihuddin Abdul. dkk. Fiqih Anti Trafficking. Yogyakarta: Pustaka Pesantren, 2006.

R. Soesilo. Kitab Undang-Undang Hukum Pidana (KUHP) Serta Komentar-Komentarnya. Bogor: Politeia, 1995.

Zahrah, Muhammad Abu. Ushul Al-Figh. terj. Saefullah Ma'shum, dkk. Jakarta: Pustaka Firdaus, t.th.

Zuhdi, Masjfuk. Masail Fighiyah: Kapita Selekta Hukum Islam. Jakarta: Haji Masagung, 1988. 